\title{
LÍNGUA DE HERANÇA: LÍNGUA BRASILEIRA DE SINAIS - LIVRO DE RONICE MÜLLER DE QUADROS
}

\author{
INHERITANCE LANGUAGE: BRAZILIAN SIGN LANGUAGE - RONICE MÜLLER DE \\ QUADROS'S BOOK
}

\section{Gigliola Duci Córdova ${ }^{1}$}

${ }^{1}$ Secretaria de Educação do Distrito Federal, Brasília gigue.cordova@gmail.com

Recebido em 30 mar. 2018

Aceito em 31 jul. 2018

QUADROS, R. M. de.; Língua de herança: língua brasileira de sinais. Porto Alegre: Penso, 2017.

Língua de herança: língua brasileira de sinais, de Ronice Quadros, discorre sobre a língua usada por indivíduos de comunidades em que outra língua é utilizada de forma mais abrangente. Normalmente, é uma língua de aspecto familiar. A obra reúne as experiências dos CODAs - filhos ouvintes de surdos brasileiros, bem como as pesquisas realizadas, no Brasil e em outros países, com usuários de línguas de sinais. Ademais, apresenta análises e relatos de pessoas que viveram situações de aquisição de línguas de herança. Sua leitura é riquíssima para profissionais que atuam na área e também para quaisquer interessados na cultura surda.

A obra está organizada em seis capítulos. O primeiro define as línguas de herança em uma perspectiva sociolinguística. O segundo capítulo apresenta os CODAs e as comunidades de língua de herança no Brasil. $O$ terceiro, destaca o caso da língua brasileira de sinais: língua de herança? ao tempo em que comprova a mudança de paradigma que a Libras sofreu ao longo dos anos, passando a ter mais valor linguístico, social e cultural, especialmente frente às comunidades surdas. O quarto capítulo oferece um apanhado das pesquisas com línguas de sinais como língua de herança. $O$ quinto capítulo discorre sobre as políticas linguísticas e a língua brasileira de sinais tomando em conta de que se trata de uma língua de herança. O sexto e último capítulo revela histórias e biografias: o que os filhos ouvintes de pais surdos contam sobre as línguas, as identidades e as culturas, tendo a própria autora como coadjuvante. O livro é bom, intenso e instigante, especialmente 
quando inspira práticas pedagógicas de ensino de línguas. É obra indispensável a qualquer profissional desta área.

O livro introduz a definição de língua de herança, bem como a caracterização do termo herança, como algo que contém e transmite de bens culturais e materiais. Com relação ao Brasil, a autora dispõe a questão bilíngue em ambiente escolar, social e familiar, vinculada à desvalorização de uma das línguas; demonstra com casos concretos e relatos importantes, como o preconceito linguístico relativo às línguas que não compreendem o Português concorre para desqualificação do status dessas línguas em relação à primeira língua oficial do país, afirmando ainda que meios de comunicação, escolas e outras instituições tendem à homogeneização linguística, favorecendo apenas uma língua.

A obra recupera a história da educação de surdos, reiterando que as línguas de sinais foram proibidas por muitos anos. Explica que a língua falada no Brasil é considerada língua oficial, usada nas escolas públicas brasileiras por determinação constitucional e que há mais de 180 outras línguas brasileiras - dentre elas, algumas de sinais - usadas por grupos minoritários.

O texto enumera pesquisadores já renomados da disciplina e acrescenta informações pertencentes ao grupo de CODAs. Através do texto, o contato com os diversos tipos de comunidades de línguas de herança é imediato, pois o livro traz vários casos para mostrar os níveis de fluência dos usuários dessas línguas. São situações de crianças que cresceram bilíngues em Inglês e Português de forma balanceada - ou seja, que possuem numerosas oportunidades de falar as duas línguas em diferentes contextos sociais - ou que cresceram entre o Português e o Alemão - com a nuance do valor social positivo para a sua primeira língua de aquisição.

Interessante relato diz respeito a uma família de surdos com duas crianças ouvintes, com níveis distintos de fluência. A autora indica que devido à convivência maior com os avós ouvintes e a postura da família com relação à surdez e ao uso da Libras, a criança com menor fluência atribuiu valor negativo à língua de sinais. 
Ronice Quadros imputa também responsabilidade pela guarda do patrimônio linguístico à comunidade usuária da língua, afirmando que é bastante difícil não ocorrer a imposição da segunda língua de aquisição sobre a primeira. Alerta que é preciso resistir ao monolinguismo imposto no país desde os tempos da apropriação do Brasil pelos portugueses.

O tema cultura surda é abordado na obra desde a definição até às pesquisas mais recentes. Serve também de mote à autora para manifestar o sentimento de entrelugares que os CODAs vivenciam durante toda a sua vida. Neste sentido, e apoiada em pesquisas que pacificam a matéria, a autora explicita os seguintes espaços que se perdem, à medida em que as línguas minoritárias não são protegidas, conforme segue: 1) dimensão histórica - a língua vai se perdendo de geração em geração, pois também de geração em geração, o contato com a língua vai se dissipando; 2) dimensão linguística - mostra a desvalorização, nos Estados Unidos, da ASL com relação ao Inglês; 3) dimensão educacional - explica a diferença entre incluir uma língua como língua de herança ou como segunda língua (ou língua estrangeira); 4) dimensão afetiva - está relacionada com as atitudes diantes das línguas, tais como desprestígio de uma língua com relação à outra; 5) dimensão cultural - relativa à identidade surda.

A autora demonstra ainda que a garantia da transmissão da língua, dentro desses contextos opressores, é feita nos espaços e momentos de encontros de surdos. Os CODAs, nestes espaço-tempos, experienciam a língua de sinais em contextos sociais fora do ambiente familiar.

Muito importante é o capítulo que trata a Libras como língua das pessoas surdas brasileiras na sua perspectiva legal. Apresenta a regulamentação; as pesquisas mais recentes, no Brasil e em outros países, e as suas formas de transmissão como língua de herança. Faz um apanhado histórico, por ocasião da lei 10.436; reitera a importância existente na garantia da preservação da história da língua de sinais, dos sinais dos surdos mais velhos; da relação - já exaustivamente demonstrada em pesquisas - de cumplicidade entre os surdos, do constructo linguístico que a Libras 
representa para esse povo, das experiências visuoespaciais que ela simboliza.

O cerne da publicação circunda a reflexão de que a primeira língua de aquisição fica em estado latente e pode ser acessada em outros momentos da vida dos usuários e que isso parece ocorrer de uma forma ainda desconhecida. Em seguida, a autora enumera várias pesquisas que tratam desses temas, conceituando o que é ser bilíngue; os níveis de proficiência no bilinguismo; aquisição tardia; pesquisas com CODAs brasileiros e americanos; e, proficiência lexical e de competência da linguagem.

Dados e análises de indicadores de fluência são apresentados e as conclusões encontradas foram que as crianças filhas de pais surdos adquirem a língua de sinais dos seus pais e a língua falante de outros contextos sociais. Essas crianças são chamadas de bilíngues bimodais e seu grau de proficiência depende de vários fatores: as escolas, o ambiente comunitário, a valorização da língua de sinais, dentre outros. O livro apresenta análise, em quadros comparativos, das semelhanças e diferenças entre os pares Português - Libras e Inglês - ASL.

A reflexão que responsabiliza as leis pelas garantias e proteção de línguas de minorias sociais, especialmente sobre a Libras, está explícita no texto. O texto demonstra que no caso do Brasil, há uma política atuante nesse sentido, mas que os tempos atuais exigem que se garanta também a manutenção da Libras, visto que há o aspecto de língua de herança contido nela. Roga o empoderamento das lideranças surdas e suas respectivas comunidades; sugere o ensino de Libras para todos os participantes da comunidade surda.

Ronice Quadros pondera ainda que o ensino de uma língua de herança não pode se basear em ensino de língua estrangeira. Apresenta, baseada em pesquisas recentes, os desafios pedagógicos que esta perspectiva contém. Enfatiza que as escolas que prevêem o ensino de Libras em seus projetos pedagógicos deverão re-organizar seus espaços educacionais.

O extenso capítulo que expõe casos de vidas de CODAs brasileiros, todos adultos, sendo a autora um deles, permite verificar as inúmeras 
tentativas de localização em um espaço-tempo próprio, a afirmativa que de é necessário saber Libras para compreender o que é ser surdo, a necessária separação profissional da relação familiar, o cotidiano entre surdos e ouvintes e, principalmente, vivências de preconceito junto à comunidade ouvinte.

Por fim, Ronice Quadros reforça que a língua é base para a constituição da comunidade surda e a relação de hereditariedade que se estabelece implica também na transmissão de valores culturais e linguísticos, de um vínculo de pertencimento com seus familiares, falantes e sinalizantes da Libras.

\section{Sobre a autora da resenha}

\section{Gigliola Duci Córdova}

Professora na Secretaria de Educação do Distrito Federal, atua como intérprete de Libras. É especialista em Libras pela UCDB e graduada em Letras pelo UniCEUB. 